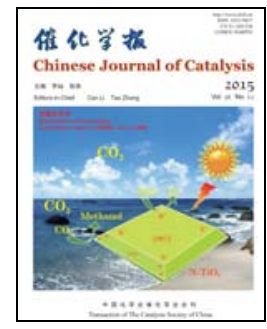

Communication (Special Issue on Photocatalysis)

\title{
Thermal nitridation of triazine motifs to heptazine-based carbon nitride frameworks for use in visible light photocatalysis
}

\author{
Zhenzhen Lin, Lihua Lin, Xinchen Wang * \\ State Key Laboratory of Photocatalysis on Energy and Environment, College of Chemistry, Fuzhou University, Fuzhou 350002, Fujian, China
}

\section{A R T I C L E I N F O}

Article history:

Received 6 September 2015

Accepted 14 October 2015

Published 20 December 2015

Keywords:

Carbon nitride

Thermal nitridation

Polymerization

Photocatalysis

Hydrogen evolution

\section{A B S T R A C T}

A thermal nitridation route for the assembly and polymerization of molecular triazine units to heptazine-based covalent frameworks has been successfully established. The obtained conjugated carbon nitride polymers feature nanostructures that show enhanced photocatalytic reactivity for hydrogen production under visible light irradiation.

(C) 2015, Dalian Institute of Chemical Physics, Chinese Academy of Sciences. Published by Elsevier B.V. All rights reserved.
Nitride-based solid-state materials have attracted a great deal of attention in many fields. For example, numerous studies have focused on the use of multifarious metal and non-metal nitrides as semiconductor photocatalysts to achieve efficient photon energy conversion [1,2]. The reported studies have clearly shown that the valence band of nitride semiconductors commonly consists of $\mathrm{N} 2 p$ orbitals or hybridized $\mathrm{N} 2 p$ and $02 p$ orbitals (such as $\mathrm{Ta}_{3} \mathrm{~N}_{5}$ and $\mathrm{TaON}$ ) above the $\mathrm{O} 2 p$ valence band of the corresponding oxides (e.g., $\mathrm{Ta}_{2} \mathrm{O}_{5}$ ). This serves to extend the photoactive region to the visible spectrum for efficient use of sunlight [3]. Therefore, many nitride semiconductors activated by visible light have been exploited and are considered as important candidates for artificial energy conversion, although the stability of these nitride-based inorganic semiconductors is a concern $[4,5]$. It is reported that surface kinetic controls using co-catalysts can significantly prevent metal nitride photocatalysts from photo-corrosion, increasing the potential of a num- ber of nitride semiconductors for use in artificial photosynthesis.

The graphitic carbon nitride (CN) polymer is a semiconductor regarded as the most stable crystal phase of the binary $\mathrm{CN}$ allotropes under ambient conditions. Since the report of $\mathrm{CN}$ redox photocatalysis in 2009 , this robust conjugated polymer, with a band gap of $\sim 2.7 \mathrm{eV}$, has stimulated a great deal of scientific interest owing to its unique and tunable optical and electronic properties [6-8]. According to previous studies, CN polymers are usually synthesized by a bulk self-polymerization reaction of $\mathrm{N}$-rich precursors at high temperature $\left(500-650{ }^{\circ} \mathrm{C}\right)$ [9-11]. The starting materials are generally the compounds containing or engendering triazine motifs in these reactions. The bulk condensation is typically limited by reaction kinetics, and the synthetic materials are not well condensed/crystalline and exhibit low specific surface areas. It has been shown that the crystallinity of a semiconductor greatly influences its pho-

\footnotetext{
* Corresponding author. Tel: +86-591-83920097; Fax: +86-591-83920097; E-mail: xcwang@fzu.edu.cn

This work was supported by the National Basic Research Program of China (973 Program, 2013CB632405), the National Natural Science Foundation of China (21425309, 21033003), the Specialized Research Fund for the Doctoral Program of Higher Education (20133514110003), and the Department of Education of Fujian Province in China.
} DOI: 10.1016/S1872-2067(15)60995-0 | http://www.sciencedirect.com/science/journal/18722067 | Chin. J. Catal., Vol. 36, No. 12, December 2015 
toredox function because the crystal structure imperfections can hamper the fast migration and separation of light-induced charge carriers $[12,13]$. Recently, it has been shown that the crystallinity of the CN polymer can be observably enhanced by heating melamine in an airtight system under an autogenic pressure of $\mathrm{NH}_{3}$, compared with that of $\mathrm{CN}$ synthesized by pyrolyzing melamine in ambient air [14]. The enhancement in crystallinity stems from the condensation reactions. However, the materials thus produced in the closed system are generally triazine-based $\mathrm{CN}$ polymers with a much reduced photocatalytic activity. Therefore, a new synthetic procedure for carbon nitride polymers is called for.

It is well known that the nitrogen in $\mathrm{NH}_{3}$ gas, generally a nucleophilic reagent, is very reactive at high temperature, reacting with metals or metal chlorides/oxides to produce metal nitrides/oxynitrides [15-17]. The nitrogen can also react with non-metal elements, such as $\mathrm{B}, \mathrm{P}$, or $\mathrm{Si}$, to yield the corresponding non-metallic nitride materials $[18,19]$. Indeed, the synthesis of nitrogen-rich carbon-based materials has been demonstrated by thermal annealing of amorphous carbon powders under $\mathrm{NH}_{3}$ atmosphere at high temperature $(>1000$ ${ }^{\circ} \mathrm{C}$ ), revealing that the nitrogen can combine with the stable carbon structure to form covalent $\mathrm{C}-\mathrm{N}$ bonds at high temperature [20]. However, the nitridation of organic molecules with $\mathrm{NH}_{3}$ at high temperature, to produce nitride semiconductors for heterogeneous photocatalysis, has not been widely reported, and thus far, the nitridation of triazine trichloride by the acid-base polymerization reaction to form covalent carbon nitride frameworks is yet to be investigated.

Herein, we introduce a thermal nitridation route for the synthesis of well-defined heptazine-based covalent carbon nitride frameworks by using $\mathrm{NH}_{3}$ and solid triazine trichloride as starting materials, and explore their photocatalytic reactivities. Our experiments show that the synthetic route allows one to nitridize the solid cyanuric trichloride into heptazine-based $\mathrm{CN}$ nanostructures at elevated temperature, as shown in Scheme 1. In the first stage of the synthesis, the gas-phase nitridation of organic molecules can produce a carbon nitride polymer composed of $s$-triazine rings from a nucleophilic substitution reaction of solid triazine trichloride with $\mathrm{NH}_{3}$. Chlorine can easily depart from the triazine trichloride to produce $\mathrm{NH}_{4} \mathrm{Cl}$ after the reaction of the formed $\mathrm{HCl}$ with $\mathrm{NH}_{3}$, and the amino group is strongly bound with carbon because the amino group is a much poorer leaving-group than chlorine [21]. Polymeric $\mathrm{CN}$ materials consisting of triazine motifs are kinetically labile with regard to their further conversion into hep-

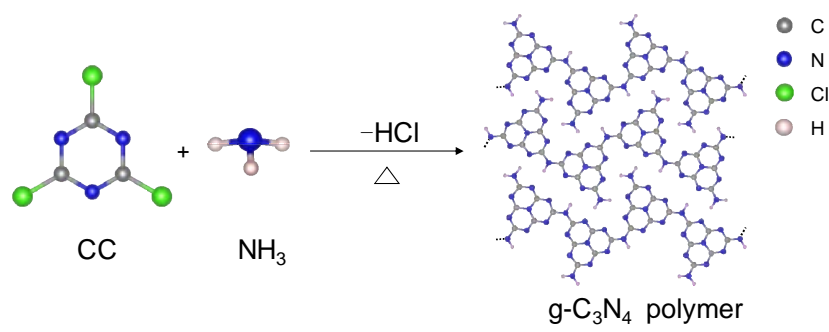

Scheme 1. Thermal nitridation induced polymerization of cyanuric trichloride (CC) to g- $\mathrm{C}_{3} \mathrm{~N}_{4}$ with flowing $\mathrm{NH}_{3}$. tazine-based carbon nitride frameworks at high temperature [22]. This nitridation process might yield well-condensed polymelon by fusion of triazine units.

In our experiments, thermal-nitridation-derived carbon nitride samples were synthesized by heating cyanuric chloride $(1.38 \mathrm{~g})$ at a certain temperature for $2 \mathrm{~h}$ with a ramp rate of 5.0 ${ }^{\circ} \mathrm{C} /$ min under flowing $\mathrm{NH}_{3}(25 \mathrm{~mL} / \mathrm{min})$. The as-synthesized products are denoted as CNC- $X$, where $X$ is an arbitrary number that represents the pyrolyzing temperature (Table 1). As a reference, melamine-derived carbon nitride ( $\mathrm{g}-\mathrm{CN})$, synthesized from the traditional thermal-condensation process, was also obtained [9]. We then investigated the properties of well-defined carbon nitride polymers prepared at different degrees of layer condensation, and studied the visible light-activated catalytic performance of the resultant CNC samples for hydrogen photosynthesis from an aqueous solution of triethanolamine.

First, we analyzed the chemical structure and composition of the products by X-ray photoelectron spectroscopy (XPS) characterization, which is sensitive to the chemical environment of lightweight elements. Signals of C, N, and 0 in the survey spectrum in Fig. 1(a) were recorded, but no peak assigned to $\mathrm{Cl}$ could be observed. The absence of $\mathrm{Cl}$ in the final sample was confirmed by the high-resolution spectra of $\mathrm{Cl} 2 p$, as shown in Fig. 1(b). The absence of $\mathrm{Cl}$ species in the as-prepared CNC solid is further confirmed by elemental analysis, and the values of the $\mathrm{C} / \mathrm{N}$ ratios are in accordance with that of the melamine-derived g-CN (Table 1). Additionally, the presence of $\mathrm{O}$ is probably the result of the $\mathrm{H}_{2} \mathrm{O}$ and $\mathrm{O}_{2}$ adsorbed on the surface of the resulting samples. The structure details relating to the framework $\mathrm{C}$ and $\mathrm{N}$ elements in the $\mathrm{CNC}-3$ sample were measured by their corresponding high-resolution spectra. The C $1 s$ XPS spectrum in Fig. 1(c) shows one main peak at 287.9 $\mathrm{eV}$, which is related to an $s p^{2}$-bonded carbon $(\mathrm{N}-\mathrm{C}=\mathrm{N})$. The other weak $\mathrm{C} 1 s$ peak at $284.6 \mathrm{eV}$ is attributed to carbon impurities [10]. In Fig. 1(d), the $\mathrm{N} 1 s$ spectrum can be deconvoluted into four peaks. The strongest $\mathrm{N} 1 s$ peak at $398.4 \mathrm{eV}$ is identified as an $s p^{2}$-bonded nitrogen $(\mathrm{C}-\mathrm{N}=\mathrm{C})$. The $\mathrm{N} 1 s$ peaks at 399.5 and $400.7 \mathrm{eV}$ are attributed to $\mathrm{N}$ atoms that are bound to three $\mathrm{C}$ atoms. The last peak at $404.1 \mathrm{eV}$ is assigned to $\pi$-excitations. This result reveals that the as-obtained CNC-3 sample is dominated by tri-s-triazine structures that are basic units of the g-CN polymer, as confirmed by the solid-state ${ }^{13} \mathrm{C}$ nuclear magnetic resonance (NMR) analysis (Fig. 2), in which there are two groups of resonances at $\delta=162.5 / 164.8$ and 156.4, separately assigned to $\mathrm{CN}_{2}\left(\mathrm{NH}_{x}\right)$ and $\mathrm{CN}_{3}$ motifs [14].

The X-ray diffraction (XRD) patterns of CNC materials are

Table 1

Physicochemical properties of g-CN and CNC samples.

\begin{tabular}{lcccc}
\hline Catalyst & $\begin{array}{c}A_{\text {BET }} \\
\left(\mathrm{m}^{2} / \mathrm{g}\right)\end{array}$ & $\begin{array}{c}\mathrm{C} / \mathrm{N} \\
\text { molar ratio }\end{array}$ & $\begin{array}{c}\text { H content } \\
(\mathrm{wt} \%)\end{array}$ & $\begin{array}{c}\text { HER } \\
(\mu \mathrm{mol} / \mathrm{h})\end{array}$ \\
\hline g-CN $^{\mathrm{b}}$ & 10 & 0.67 & 1.91 & 12 \\
CNC-1 $^{\mathrm{c}}$ & 26 & 0.66 & 2.04 & 68 \\
CNC-2 $^{\mathrm{c}}$ & 54 & 0.67 & 1.76 & 101 \\
CNC-3 $^{\mathrm{c}}$ & 69 & 0.68 & 1.61 & 120 \\
\hline
\end{tabular}

${ }^{a} \mathrm{H}_{2}$ evolution rate.

b Synthesized by heating melamine at $550{ }^{\circ} \mathrm{C}$ in air.

'The numbers 1,2 , and 3 correspond to reaction temperatures of 500 , 550 , and $600{ }^{\circ} \mathrm{C}$, respectively. 

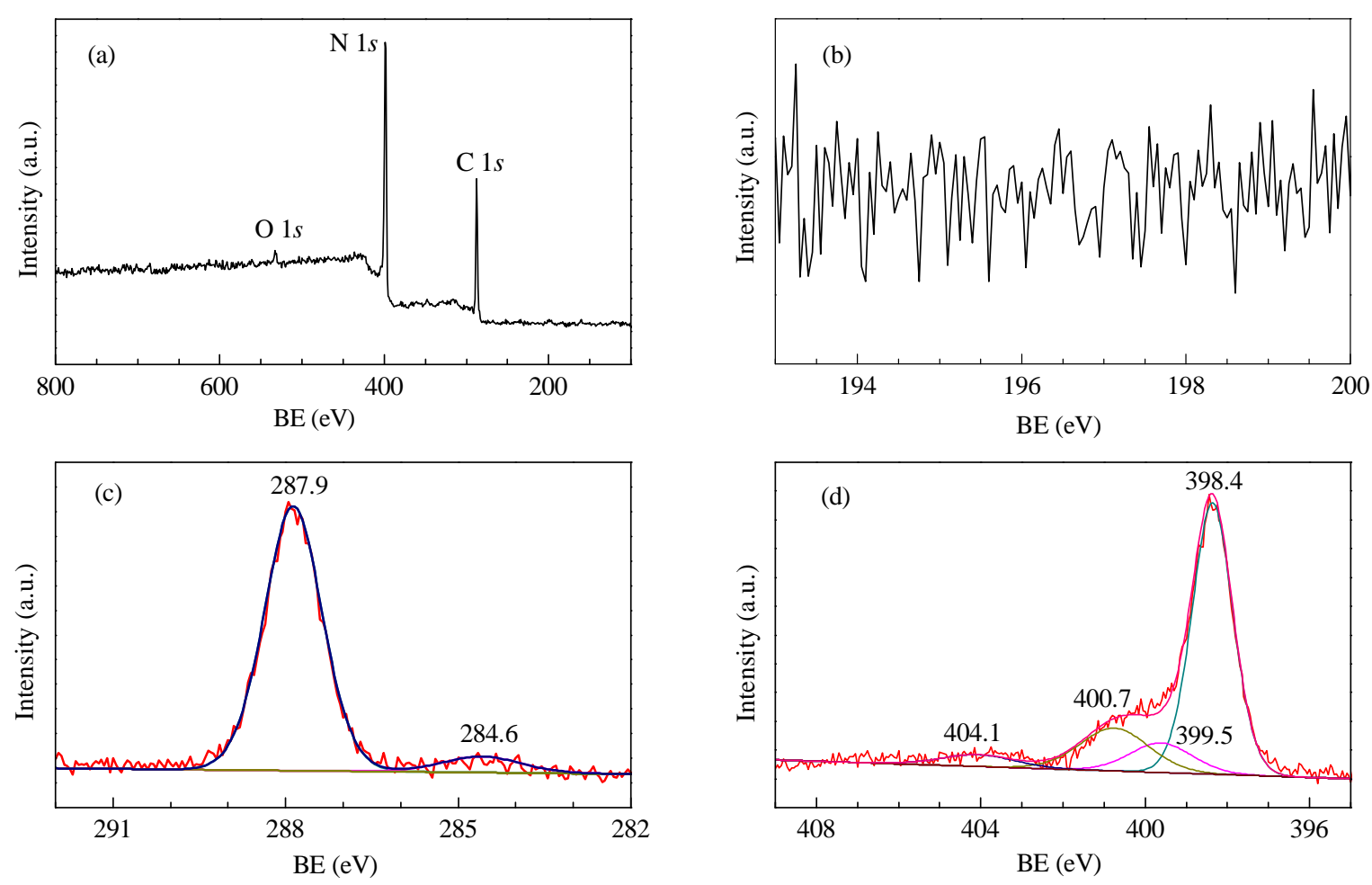

Fig. 1. XPS survey spectrum of the CNC-3 sample (a) and the corresponding high-resolution XPS spectra of Cl $2 p$ (b), C $1 s$ (c), and N $1 s$ (d).

analogous to that of bulk g-CN in Fig. 3(a), which is governed by the characteristic interlayer stacking (002) peak and in-plane repeating motifs (100) peak [9]. This result indicates a graphitic layer structure for CNC samples, similar to that of g-CN. A careful analysis of Fig. 3(b) revealed a clear shift of the (002) peak from g-CN at $27.5^{\circ}$ to $\mathrm{CNC}-3$ at $27.8^{\circ}$, revealing a reduction in the interlayer stacking distance from 0.325 to $0.322 \mathrm{~nm}$ [23]. Additionally, the CNC materials in Fig. 3(c) exhibited narrower (002) peaks than those of the melamine-derived g-CN, indicating a higher degree of crystalline order for the nitridation products compared with that of the reference. It should be noted that all CNC products feature some residual amount of hydrogen that is also characterized in normal g-CN, which decreases with increased condensation temperature (Table 1).

The well-resolved and strong fourier transformed infrared (FT-IR) absorption bands further support the formation of the

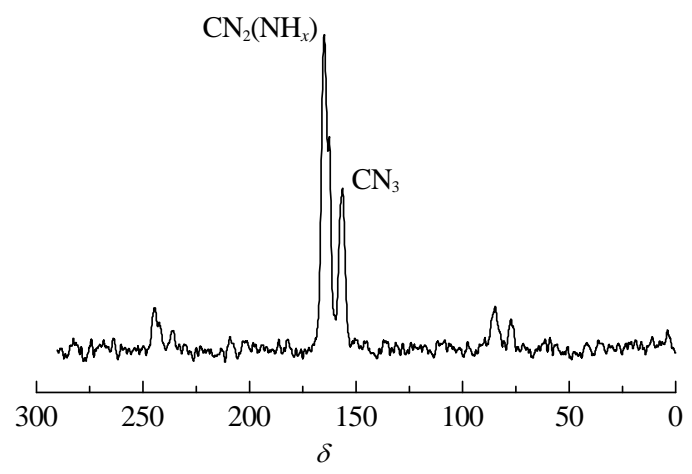

Fig. 2. Solid-state ${ }^{13} \mathrm{C}$ NMR spectrum of the CNC-3 sample. carbon nitride structure. In Fig. 3(d), all CNC solids in the $1200-1600 \mathrm{~cm}^{-1}$ region feature several stretching vibrations of aromatic $\mathrm{CN}$ heterocycles, together with a typical breathing mode of triazine units at $800 \mathrm{~cm}^{-1}$. The results are consistent with the IR observations for the melamine-derived sample. These results demonstrate that we have successfully prepared the heptazine-based carbon nitride frameworks through this modified thermal condensation approach.

The morphology and microstructure of g-CN and CNC-3 samples were investigated by transmission electron microscopy (TEM), as shown in Fig. 4. The thin-slice-like CNC-3 sample is quite different from the reference sample composed of bulky platelet-like solid agglomerates in Fig. 4(a), probably owing to the use of the active precursors that ameliorates the kinetic hindrance of the solid-state reaction. In some regions, curved layers were also recorded for the CNC-3 sample in Fig. 4(b) and (c), which is conducive to the reduction of surface tension. This is somewhat similar to the case of the presence of carbon scrolls in graphene. The formation of nanosheet morphology was further confirmed by atomic force microscopy (AFM). In the cross-sectional AFM image in Fig. 4(d), we can observe several nanosheets present on the surface of a mica wafer. The nanosheets have a uniform thickness of approximately 3-6 nm.

The data obtained from $\mathrm{N}_{2}$ adsorption-desorption measurements (Table 1) reveal that the specific surface area of CNC samples is larger than that of the reference sample. This opened-up nanosheet structure with enlarged surface area would provide multiple active sites, facilitate surface chemical species transfer, and promote charge separation, which are all characteristics that are desirable for surface-dependent photochemical reactions. 

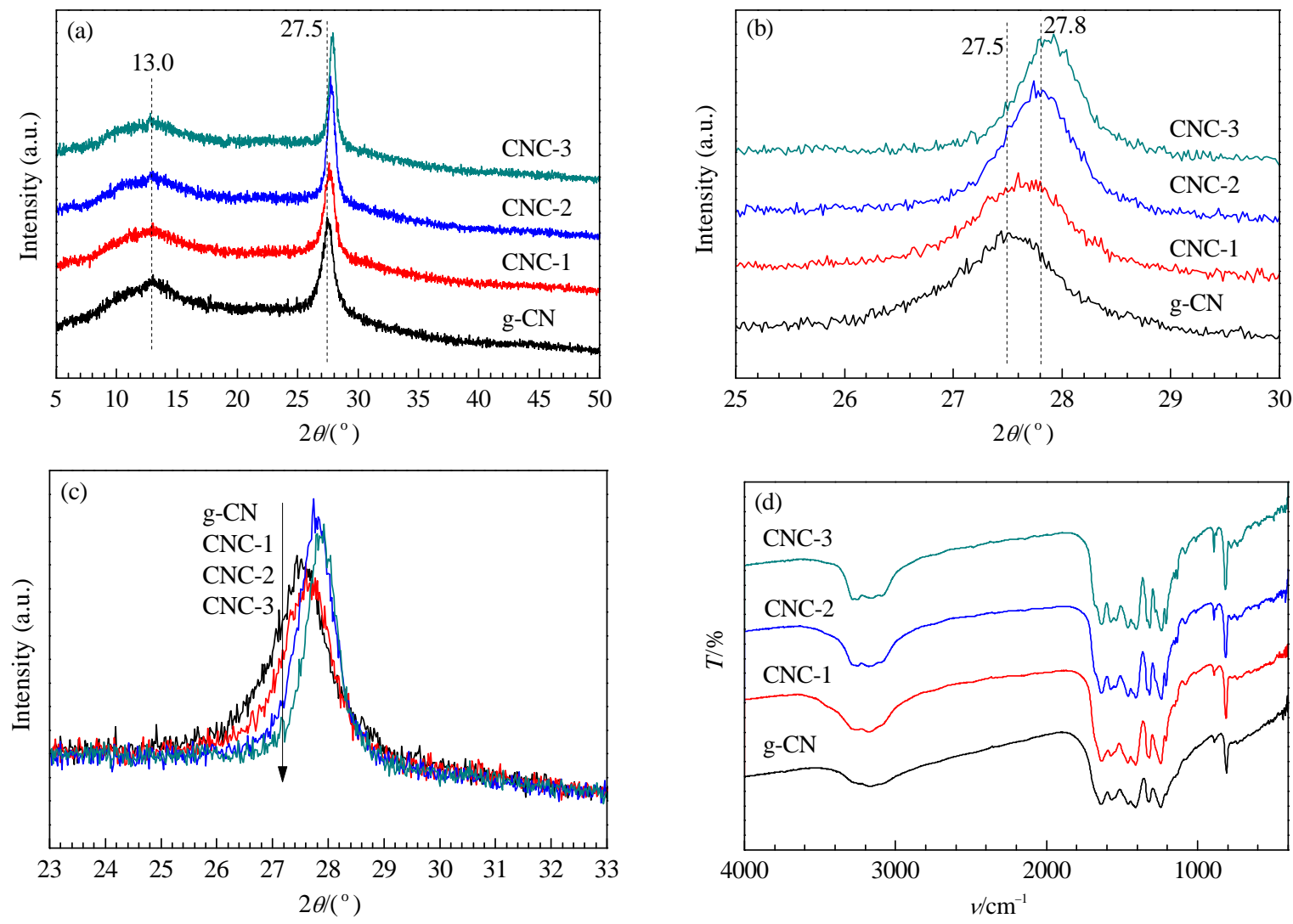

Fig. 3. XRD patterns (a, b, c) and FT-IR spectra (d) of the g-CN and CNC- $X$ samples.

Changing the thermal conditions enables the fine adjustment of the electronic and optical features, as revealed by the UV-vis diffuse reflectance spectra for CNC samples shown in Fig. 5. Typical semiconductor absorption with a band gap of $2.95 \mathrm{eV}$ is observed for CNC-3 and $2.69 \mathrm{eV}$ for $\mathrm{g}-\mathrm{CN}$. We propose that the obvious blue shift of the absorption edge

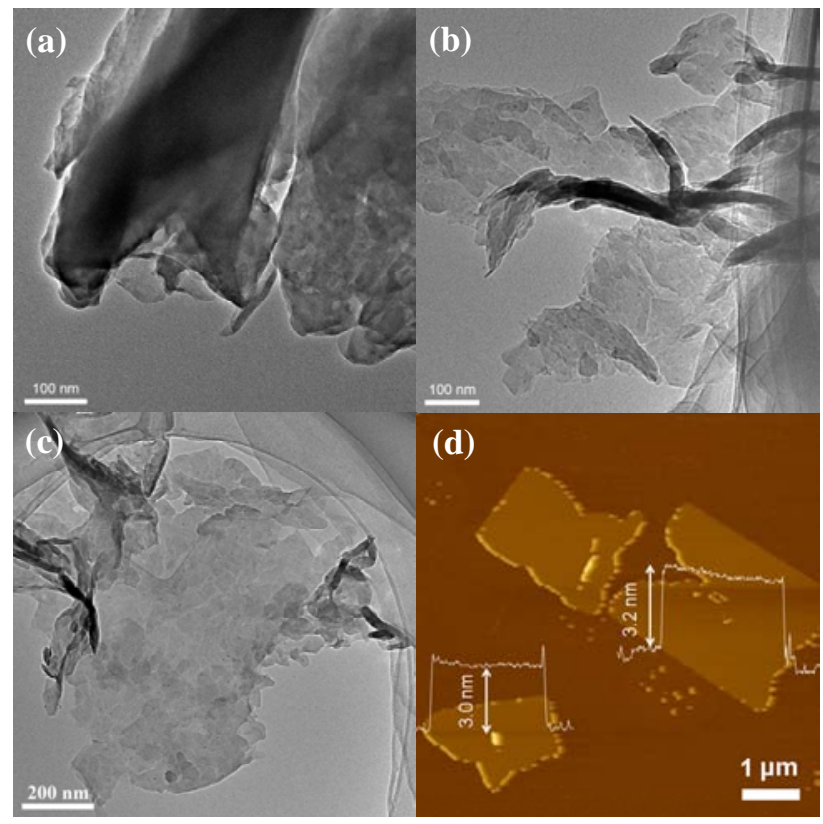

Fig. 4. TEM images of g-CN (a) and $\mathrm{CNC}-3$ (b, c), and AFM image of CNC-3 (d). arises from the structure disorder and enlarged surface area. Indeed, a similar hypsochromic-shift has been observed for the reported carbon nitride-based samples with a denser packing and enlarged surface area [24-26].

Photo-assisted hydrogen production was then performed under visible light excitation of greater than $410 \mathrm{~nm}$, using a water-triethanolamine solution. Pt was used as a cocatalyst, owing to its well-known low over-potential for water reduction. Both $\mathrm{CNC}$ samples and reference g-CN are active photocatalysts for $\mathrm{H}_{2}$ generation, as recorded in Table 1. The performance of $\mathrm{g}-\mathrm{CN}$, in terms of hydrogen evolution rate

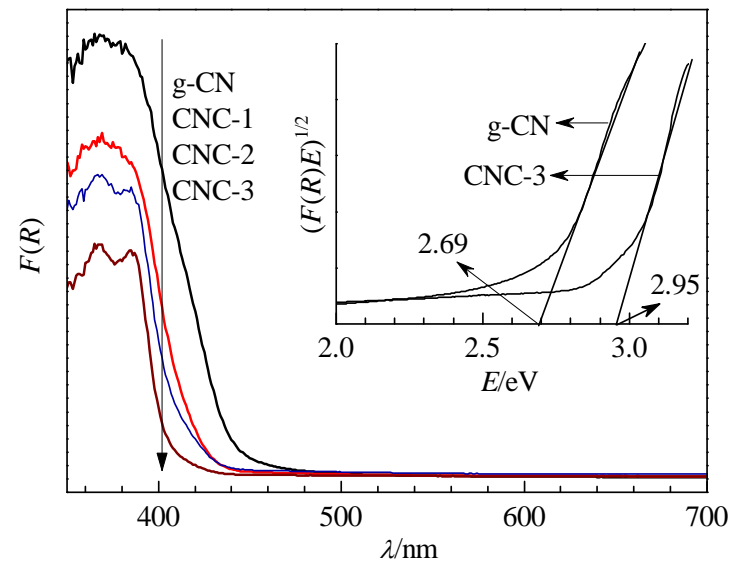

Fig. 5. UV-vis diffuse reflectance spectra of CNC- $X$, with g-CN as reference and the corresponding Tauc plot (inset). 


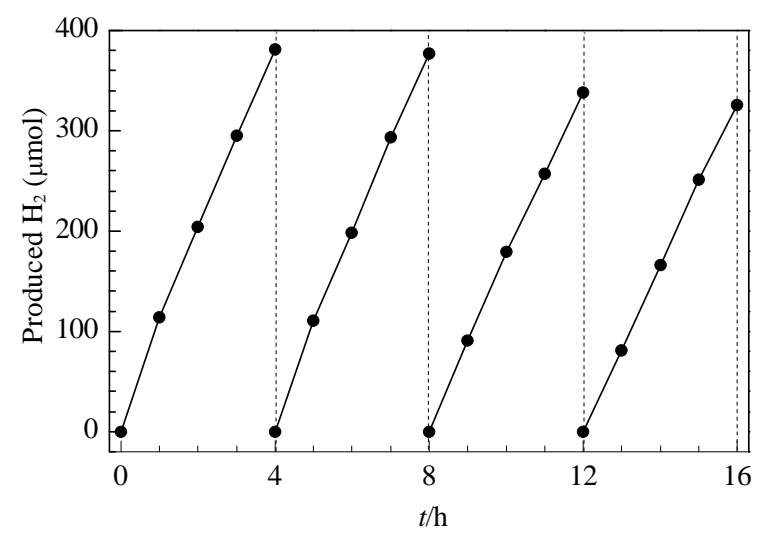

Fig. 6. Stability test of $\mathrm{H}_{2}$ photosynthesis (evacuation every $4 \mathrm{~h}$ ) for the CNC-3 sample with visible light irradiation $(\lambda>410 \mathrm{~nm})$.

(HER), was $12 \mu \mathrm{mol} / \mathrm{h}$, which is clearly lower than those of CNC materials $(\mathrm{HER}=68,101,120 \mu \mathrm{mol} / \mathrm{h}$ for CNC-1, CNC-2, and CNC-3, respectively). Generally, the activity of the photocatalysts relates to a series of parameters, such as optical absorption, surface area, absorption capacity, charge carrier recombination rate and morphology. In our case, with increasing temperature, the absorption of the CNC samples in the visible region decreased, indicating that the optical properties are not the main factor that affects the catalytic performance. Hence, the observed improvement of photoactivity, relative to the g-CN, may be associated with an increase in surface area, an alternative nanosheet morphology that facilitates surface species transfer and charge-carrier separation, as well as the reduced protonation status [11]. We also measured their photocatalytic stability, which is acknowledged as an important parameter for evaluating a photocatalyst. Figure 6 shows a typical time course of $\mathrm{H}_{2}$ evolution. A stable $\mathrm{H}_{2}$ release rate of approximately 120 $\mu \mathrm{mol} / \mathrm{h}$ was observed for CNC-3. Moreover, there was only a slight reduction of the photoactivity after illumination for four continuous runs, indicating a good stability of the sample.

In summary, we have used a thermal nitridation approach for the reaction of solid triazine trichloride with $\mathrm{NH}_{3}$ to achieve conjugated heptazine-based $\mathrm{CN}$ framewoks. The visible light-activated CNC samples all photocatalyze $\mathrm{H}_{2}$ generation from an aqueous triethanolamine solution, and exhibit a much higher reactivity compared with the g-CN catalyst. The developed nanostructures exhibit reduced dimension, greater surface areas, good crystallinity, and suitable band structure. These characteristics are proposed to all contribute to the efficient photoreactivity. This thermal nitridation route, using reactive $\mathrm{NH}_{3}$ as a starting material for the preparation of $\mathrm{CN}$ polymers combined with efficient visible light activity, is also of significant interest for yielding different modifications of CN-based catalysts for solar energy application [27].

\section{References}

[1] Seo J, Takata T, Nakabayashi M, Hisatomi T, Shibata N, Minegishi T, Domen K. J Am Chem Soc, 2015, 137: 12780

[2] Huang C J, Chen C, Zhang M W, Lin L H, Ye X X, Lin S, Wang X C, Antonietti M. Nat Commun, 2015, 6: 7698

[3] Maeda K, Domen K.J Phys Chem C, 2007, 111: 7851

[4] Hisatomi T, Kubota J, Domen K. Chem Soc Rev, 2014, 43: 7520

[5] Zheng Y, Lin L H, Wang B, Wang X C. Angew Chem Int Ed, 2015, DOI: 10.1002/anie.201501788R1

[6] Wang X C, Maeda K, Thomas A, Takanabe K, Xin G, Carlsson J M, Domen K, Antonietti M. Nat Mater, 2009, 8: 76

[7] Wang Y, Wang X C, Antonietti M. Angew Chem Int Ed, 2012, 51: 68

[8] Zhang J S, Chen Y, Wang X C. Energy Environ Sci, 2015, DOI: 10.1039/C5EE01895A

[9] Yan S C, Li Z S, Zou Z G. Langmuir, 2009, 25: 10397

[10] Zhang G G, Zhang J S, Zhang M W, Wang X C. J Mater Chem, 2012, 22: 8083

[11] Martin D J, Qiu K P, Shevlin S A, Handoko A D, Chen X W, Guo Z X, Tang J W. Angew Chem Int Ed, 2014, 53: 9240

[12] Kato H, Asakura K, Kudo A. J Am Chem Soc, 2003, 125: 3082

[13] Joo J B, Zhang Q Dahl M, Lee I, Goebl J, Zaera F, Yin Y D. Energy Environ Sci, 2012, 5: 6321

[14] Lotsch B V, Doblinger M, Sehnert J, Seyfarth L, Senker J, Oeckler O, Schnick W. Chem Eur J, 2007, 13: 4969

[15] Kado Y, Lee C Y, Lee K, Muller J L, Moll M, Spiecker E, Schmuki P. Chem Commun, 2012, 48: 8685

[16] Li M X, Luo W J, Cao D P, Zhao X, Li Z S, Yu T, Zou Z G. Angew Chem Int Ed, 2013, 52: 11016

[17] Suzuki A, Hirose Y, Oka D, Nakao S, Fukumura T, Ishii S, Sasa K, Matsuzaki H, Hasegawa T. Chem Mater, 2014, 26: 976

\section{Graphical Abstract}

Chin. J. Catal., 2015, 36: 2089-2094 doi: 10.1016/S1872-2067(15)60995-0

Thermal nitridation of triazine motifs to heptazine-based carbon nitride frameworks for use in visible light photocatalysis

Zhenzhen Lin, Lihua Lin, Xinchen Wang *

Fuzhou University

A facile thermal nitridation route has been developed for the synthesis of covalent carbon nitride frameworks for $\mathrm{H}_{2}$ photosynthesis.

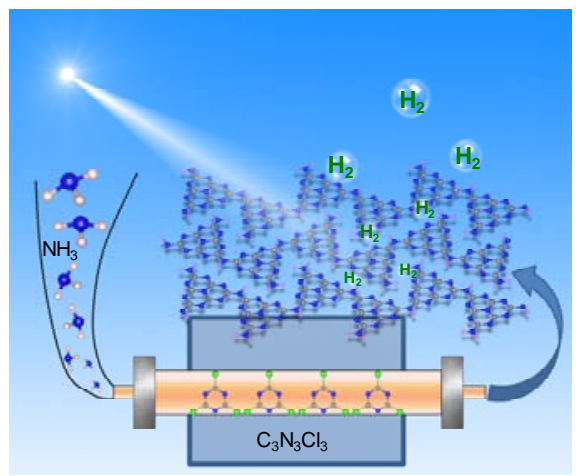


[18] Schnick W. Angew Chem Int Ed Engl, 1993, 32: 806

[19] Li L, Li L H, Chen Y, Dai X J, Lamb P R, Cheng B M, Lin M Y, Liu X W. Angew Chem Int Ed, 2013, 52: 4212

[20] Gong Z G, Li M S. Chin Phys Lett, 2003, 20: 1540

[21] Loudon J D, Shulman N.J Chem Soc, 1941: 722

[22] Lotsch B V, Schnick W. Chem Mater, 2006, 18: 1891

[23] Jorge A B, Martin D J, Dhanoa M T S, Rahman A S, Makwana N, Tang J W, Sella A, Cora F, Firth S, Darr J A, McMillan P F. J Phys
Chem C, 2013, 117: 7178

[24] Chen Y, Wang B, Lin S, Zhang Y F, Wang X C. J Phys Chem C, 2014, 118: 29981

[25] Wang X L, Fang W Q, Yang S, Liu P F, Zhao H J, Yang H G. RSC Adv, 2014, 4: 10676

[26] Zhang M W, Wang X C. Energy Environ Sci, 2014, 7: 1902

[27] Martin D J, Reardon P J T, Moniz S J A, Tang J W. J Am Chem Soc, 2014, 136: 12568

\title{
高温氮化热聚合法制备氮化碳框架材料用于可见光光催化反应
}

\author{
林珍珍，林励华，王心晨 ${ }^{*}$ \\ 福州大学化学学院能源与环境光催化国家重点实验室, 福建福州 350002
}

摘要: 石墨相氮化碳是一种聚合物半导体材料(带隙宽度约为 $2.7 \mathrm{eV}$ ), 具有独特的和可调控的光学和电子性质, 能够作为半导体光 催化剂用于驱动一系列光催化反应, 在能源和环境领域具有潜在应用前景. 利用简单的热聚合法, 在空气或氮气中高温焙烧 $\left(500700^{\circ} \mathrm{C}\right)$ 富氮前驱体可以合成氮化碳聚合物. 通常, 这些富氮前驱物含有三嗪单元(如三聚氭胺和三聚硫氰酸原料)或在热聚 合过程中会生成三嗪单元(如氧胺和二聚氭胺原料). 由于热聚合反应过程受到反应动力学限制, 氮化碳半导体材料的聚合度和结 晶度不高,且比表面积较小, 使其在光催化反应过程中存在传质作用差、激子结合能高和光生载流子复合严重等问题, 不利于光催 化反应进行. 本课题组发展了氮化碳光催化剂的合成新方法(高温氮化), 该方法抑制了热聚合过程中三嗪中间体的快速分解, 促 进了氮化碳的聚合. 我们将所制备的催化剂用于光催化分解水产氢反应, 发现高温氮热反应制备的氮化碳样品(CNC)的催化性能 显著优于传统氮化碳. 傅立叶红外光谱(FT-IR)、X射线光电子能谱(XPS) 和 ${ }^{13} \mathrm{C}$ 固体核磁共振谱 $\left({ }^{13} \mathrm{C} N \mathrm{NR}\right)$ 的表征结果表明, CNC 光催化剂具有与传统氮化碳类似的化学结构和组成(七嗪基本结构单元). 然而, 对于高温氮化热聚合方法制备得到的七嗪基氮化 碳聚合物光催化性能增强的原因并不清楚. 基于此, 本文采用X射线粉末衍射(XRD)、场发射透射电镜(FE-TEM)、原子力显微镜 (AFM)和比表面积(BET)测试等手段研究了不同制备方法得到的氮化碳基光催化剂在可见光光催化分解水产氢反应中催化性能 差异的原因.

XRD结果表明, CNC系列样品的XRD谱与体相氮化碳相似, 具有石墨相氮化碳特征的层间堆积(002)衍射峰和面内重复单元 (100)衍射峰. 与传统石墨相氮化碳相比, CNC在 $27^{\circ}$ 附近的衍射峰发生明显偏移. 其 $(002)$ 晶面衍射峰从 $27.5^{\circ}$ 增大到 $27.8^{\circ}$, 使 $(002)$ 晶面间距从 $0.325 \mathrm{~nm}$ 减小到 $0.322 \mathrm{~nm}$. 进一步观察发现, CNC系列样品与体相氮化碳相比, 其衍射峰出现明显窄化, 且衍射强度增 加, 表明由高温氮化热聚合法制得的产物具有更好的结晶度. 通常, 半导体晶体结构缺陷会阻碍光生载流子的快速迁移和分离, 提高氮化碳聚合物的结晶度可有效改善其光催化氧化还原反应.

TEM结果表明, 传统石墨相氮化碳是由大块的(厚重的)片层堆积形成, 而高温氮化合成的CNC-3则是由纳米薄片组成, 这 种形貌差异可能是因为活性前驱体(氨气和三聚氭氯)的使用改善了反应动力学过程. 另外, CNC-3纳米片上有一些地方发生 卷曲, 这种卷曲能够有效减小纳米片表面张力, 降低其表面能, 使纳米片结构稳定存在, 类似于石墨烯中的碳卷曲行为. CNC-3的AFM结果进一步证实形成了纳米片结构, 其厚度均匀, 约为 3-6 nm. 我们构筑的这种纳米薄片结构具有高度敞开的平 面结构,有利于光生电子-空穴从体相迁移到表面, 可有效提高半导体的光催化性能.

BET结果表明, CNC系列样品的比表面积均比传统g- $\mathrm{C}_{3} \mathrm{~N}_{4}$ 的比表面积大, 且随焙烧温度升高而增大. CNC光催化剂增大的比 表面积改善了多相光催化反应的传质扩散过程, 增加了表面反应活性位, 有利于提高氮化碳聚合物的光催化活性.

关键词: 氮化碳; 高温氮化; 聚合反应; 光催化; 产氢

收稿日期: 2015-09-06. 接受日期: 2015-10-14. 出版日期: 2015-12-20.

*通讯联系人. 电话/传真: (0591)83920097; 电子信箱: xcwang@fzu.edu.cn

基金来源：国家重点基础研究发展计划(973计划, 2013CB632405); 国家自然科学基金(21425309, 21033003); 高等学校博士学科 点专项科研基金(20133514110003); 福建省教育厅.

本文的英文电子版由Elsevier出版社在ScienceDirect上出版(http://www.sciencedirect.com/science/journal/18722067). 